\title{
HUBUNGAN PENGETAHUAN PERAWAT DENGAN PENCEGAHAN KESELAMATAN PASIEN RISIKO JATUH PADA PASIEN PASCA OPERASI DI RUMAH SAKIT KOTA SEMARANG
}

\author{
Reza Naiz Fauzi*Achmad Syaifudin**Dwi Kustriyanti** \\ STIKes Karya Husada Semarang \\ rezanaiz@gmail.com
}

\begin{abstract}
Abstrak
Keselamatan pasien (patient safety) adalah suatu sistem dimana rumah sakit membuat asuhan pasien lebih nyaman. Hal ini termasuk assesment resiko, indentifikasi dan pengelolaan hal yang berhubungan dengan resiko pasien, pelaporan dan analisis insiden, kemampuan belajar dari insiden dan tindak lanjutnya serta implementasi solusi untuk meminimalkan timbulnya resikoWorld Health Organization (WHO) pada tahun 2011 mengumpulkan angka - angka penelitian rumah sakit di berbagai Negara antara lain Amerika, Inggris, Denmark, dan Australia, ditemukan kejadian tidak diharapkan (KTD) dengan rentang 3,2 16,6\%. Data - data tersebut menjadikan pemicu berbagai negara segera melakukan penelitian dan mengembangkan sistem keselamatan pasien. Data di Indonesia tentang kejadian tidak diharapkan (KTD) apalagi Kejadian Nyaris Cedera (Near Miss) masih langka, namun dilain pihak terjadi peningkatan tuduhan "mal praktek", yang belum tentu sesuai dengan pembuktian akhir. Insidensi pelanggaran patient safety $(28,3 \%)$ dilakukan oleh perawat. Tujuan penelitian ini untuk mengetahui hubungan pengetahuan perawat tentang patient safety dengan tindakan pencegahan resiko jatuh pada pasien post operasi di RSUD Kota Semarang, penelitian ini menggunakan jenis penelitian kuantitatif dengan desain analitik kolerasi dengan rancangan penelitian cross sectional. Populasi dalam penelitian ini adalah semua perawat RSUD Kota Semarang berjumlah 330 dengan sampel 35 responden. Hasil penelitian ada hubungan pengetahuan perawat tentang patient safety dengan tindakan pencegahan resiko jatuh pada pasien post operasi di RSUD Kota Semarang.
\end{abstract}

Kata Kunci : Pengetahuan Perawat,Patient Safety, Resiko Jatuh, Post Operation

\section{RELATIONSHIP OF NURSE KNOWLEDGE AND PATIENT SAFETY PREVENTION OF FALL RISK IN PATIENTS POST OPERATION AT SEMARANG CITY HOSPITAL}

\begin{abstract}
Patient safety is a system where hospitals make patient care more comfortable. This includes risk assessment, identification and management of matters relating to patient risk, incident reporting and analysis, the ability to learn from incidents and their follow-up and implementation of solutions to minimize risk. The World Health Organization (WHO) in 2011 compiled hospital research figures. in various countries including America, England, Denmark, and Australia, unexpected events (KTD) were found with a range of $3.2-16.6 \%$. These data trigger various countries to immediately conduct research and develop patient safety systems. Data in Indonesia regarding unexpected events (KTD), especially near misses, are still scarce, but on the other hand there is an increase in accusations of "malpractice", which are not necessarily in accordance with the final evidence. The incidence of patient safety violations $(28.3 \%)$ was carried out by nurses. The purpose of this study was to determine the relationship between nurses' knowledge about patient safety and prevention of falls in postoperative patients at the Semarang City Hospital, this study used a quantitative research type with a correlation analytic design with a cross sectional research design. The population in this study were all nurses at the Semarang City Hospital totaling 330 with a sample of 35 respondents. The results of the study showed that there was a relationship between nurses' knowledge about patient safety and preventive measures for the risk of falling in postoperative patients at the Semarang City Hospital.
\end{abstract}

Keywords: Nurse Knowledge, Patient Safety, Fall Risk, Post Operation 


\section{Pendahuluan}

Keselamatan pasien (patient safety) adalah suatu sistem dimana rumah sakit membuat asuhan pasien lebih nyaman. Hal ini termasuk assesment resiko, indentifikasi dan pengelolaan hal yang berhubungan dengan resiko pasien, pelaporan dan analisis insiden, kemampuan belajar dari insiden dan tindak lanjutnya serta implementasi solusi untuk meminimalkan timbulnya resiko. Sistem ini mencegah terjadinya cidera yang disebabkan oleh kesalahan akibat melaksanakan suatu tindakan atau tidak mengambil tindakan yang seharusnya dilakukan (Depkes, 2012). World Health Organization (WHO) pada tahun 2011 mengumpulkan angka - angka penelitian rumah sakit di berbagai Negara antara lain Amerika, Inggris, Denmark, dan Australia, ditemukan kejadian tidak diharapkan (KTD) dengan rentang 3,2 - 16,6\%. Data - data tersebut menjadikan pemicu berbagai negara segera melakukan penelitian dan mengembangkan sistem keselamatan pasien (Depkes, 2008).

Data di Indonesia tentang kejadian tidak diharapkan (KTD) apalagi Kejadian Nyaris Cedera (Near Miss) masih langka, namun dilain pihak terjadi peningkatan tuduhan "mal praktek", yang belum tentu sesuai dengan pembuktian akhir. Insidensi pelanggaran patient safety $(28,3 \%)$ dilakukan oleh perawat. Perawat harus menyadari perannya sehingga harus dapat berpartisipasi aktif dalam mewujudkan patient safety. Kerja keras perawat tidak dapat mencapai level optimal jika tidak didukung dengan sarana prasarana, manajemen rumah sakit dan tenaga kesehatan lainnya (Adib, 2009).

Penelitian serupa tentang kepatuhan perawat melaksanakan standar prosedur operasional pencegahan pasien resiko jatuh digedung Yosef 3 Dago dan Surya Kencana rumah sakit Boromeus, oleh Setyarini (2013) menyimpulkan bahwa kepatuhan perawat Yosef

3 Dago dan Surya Kencana patuh 75\% melaksanakan SPO pencegahan pasien resiko jatuh sedangkan hasil penelitian tentang hubungan pengetahuan dan sikap perawat dengan pelaksanaan keselamatan pasien (patient safety) diruang rawat inap RSUD Liun Kendage Tahuna, oleh Selleya (2013) menyimpulkan bahwa ada hubungan sikap perawat dengan pelaksanaan keselamatan pasien diruang rawat inap RSUD Liun Kendage Tahuna, dimana 95\% perawat pelaksana mempunyai pengetahuan baik tentang pelaksanaan keselamatan pasien

Hasil studi pendahuluan yang peneliti lakukan di ruang Prabu Kresna RSUD Kota Semarang yaitu melalui wawancara kepada 10 perawat menyatakan bahwa sejumlah $70 \%$ perawat mengetahui tentang patient safety dan pencegahan resiko jatuh pada pasien namun belum sepenuhnya menerapkan pencegahan tersebut, sedangkan wawancara pada $30 \%$ perawat kurang mengetahui tentang patient safety dan pencegahan pada pasien resiko jatuh serta belum menerapkan pencegahan pada pasien. Bedasarkan observasi yang dilakukan didapat bed pasien tidak ada pagar pengaman, kasur sudah mulai rusak, lampu penerangan remang-remang, tidak berfungsinya tombol pemanggil perawat, tidak adanya tanda peringatan pasien beresiko jatuh.

\section{Metode Penelitian}




\section{Hasil dan pembahasan}

jenis penelitian ini adalah kuantitaif dengan desain analitik korelasi. Penelitian ini dilakukan di Ruang Nakula I dan Prabu Kresna. Populasi dalam penelitian ini adalah semua perawat yang ada di bangsal RSUD Kota Semarang sejumlah 330 sedangkan sampel yang memenuhi kriteria inklusi dan ekslusi sebanyak 30 responden. Penelitian ini menggunakan rancangan penelitian cross sectional. Penelitian ini dilakukan pada bulang Mei- Agustus 2015 menggunakan lembar kuesioner dan lembar observasi sebelum mengisi lembar kuesioner responden terlebih dahulu mengisi inform consent.

\section{Hasil}

Tabel 4.1 Distribusi frekuensi umur perawat diRSUD Kota Semarang.

\begin{tabular}{llllll}
\hline $\mathrm{n}$ & Mean & Std. Deviation & Median & Min & Max \\
\hline 35 & 32.33 & 8.394 & 28.00 & 24 & 50 \\
\hline
\end{tabular}

Berdasarkan tabel 4.1. di atas maka dapat diketahui bahwa perawat di RSUD Kota Semarang mempunyai umur rata-rata 32, 22 tahun, median 28 tahun, standar deviation 8,394 dengan umur termuda 24 tahun dan umur tertua 50 tahun.

Tabel 4.2 Distribusi frekuensi jenis kelamin perawat RSUD Kota Semarang.

\begin{tabular}{ccc}
\hline Jenis Kelamin & Frekuesni & Prosentase (\%) \\
\hline Laki-laki & 15 & 42.9 \\
\hline Perempuan & 20 & 57.1 \\
\hline Total & 35 & 100 \\
\hline
\end{tabular}

Berdasarkan tabel di atas maka dapat diketahui bahwa perawat di RSUD Kota Semarang sebagian besar mempunyai jenis kelamin perempuan sebanyak 20 responden $(57,1 \%)$ dan sebagian kecil mempunyai jenis kelamin laki- laki sebanyak 15 responden $(42,9 \%)$.

Tabel 4.3 Distribusi frekuensi tingkat pendidikan perawat tentang patient safety di RSUD Kota Semarang.

\begin{tabular}{ccc}
\hline $\begin{array}{c}\text { Tingkat } \\
\text { Pendidikan }\end{array}$ & Frekuesni & Prosentase (\%) \\
\hline $\begin{array}{c}\text { DIII } \\
\text { Keperawatan }\end{array}$ & 24 & 68.6 \\
\hline S1 Keperawatan & 11 & 31.4 \\
\hline Total & 35 & 100 \\
\hline
\end{tabular}

Berdasarkan tabel di atas maka dapat diketahui bahwa perawat di RSUD Kota Semarang sebagian 
besar mempunyai pendidikan DIII Keperawatan sebesar 24 responden $(68,6 \%)$ dan sebagian kecil mempunyai pendidikan S1 keperawatan sebanyak 11 responden $(31,4 \%)$.

Tabel 4.4 Distribusi frekuensi lama kerja perawat tentang patient safety di RSUD Kota

\begin{tabular}{llllll}
\hline $\mathrm{n}$ & Mean & Std. Deviation & Median & Min & Max \\
\hline 35 & 7.342 & 6.324 & 5.000 & 2 & 25 \\
\hline
\end{tabular}

Berdasarkan tabel diatas maka dapat diketahui bahwa perawat di RSUD Kota Semarang mempunyai lama kerja rata-rata 7,342 tahun, median 5.00 tahun, standart deviation 6,324 dengan lama bekerja terendah 2 tahun dan tertinggi 24 tahun.

Tabel 4.5 Distribusi frekuensi tingkat pengetahuan perawat tentang patient safety di RSUD Kota Semarang

\begin{tabular}{ccc}
\hline $\begin{array}{c}\text { Tingkat } \\
\text { Pengetahuan }\end{array}$ & Frekuesni & Prosentase (\%) \\
\hline Baik & 15 & 42.9 \\
\hline Cukup & 13 & 37.1 \\
\hline Kurang & 7 & 20.0 \\
\hline Total & 35 & 100 \\
\hline
\end{tabular}

Berdasarkan tabel di atas maka dapat diketahui bahwa perawat di RSUD Kota Semarang sebagian besar mempunyai pengetahuan baik sebanyak 15 responden $(42,9 \%)$ dan sebagian kecil mempunyai pengetahuan kurang sebanyak 7 responden $(20,0 \%)$.

Tabel 4.6 Distribusi frekuensi tindakan pencegahan perawat tentang patient safety di RSUD Kota Semarang

\begin{tabular}{ccc}
\hline $\begin{array}{c}\text { Tingkat } \\
\text { Pengetahuan }\end{array}$ & Frekuesni & Prosentase (\%) \\
\hline Baik & 20 & 57.1 \\
\hline Kurang Baik & 15 & 42.9 \\
\hline Total & 35 & 100 \\
\hline
\end{tabular}

Berdasarkan tabel di atas maka dapat diketahui bahwa perawat di RSUD Kota Semarang sebagian besar mempunyai tindakan baik sebanyak 20 responden $(57,1 \%)$ dan sebagian kecil mempunyai tindakan kurang baik sebanyak 15 responden $(42,9 \%)$.

Tabel 4.7 Hubungan pengetahuan perawat tentang patient safety dengan tindakan pencegahan resiko jatuh pada pasien post operasi di RSUD Kota Semarang

\begin{tabular}{lrrrrrrrr}
\hline \multirow{2}{*}{ Pengetahuan } & \multicolumn{4}{c}{ Tindakan } & \multirow{2}{*}{$\begin{array}{c}\text { P } \\
\text { Value }\end{array}$} \\
\cline { 2 - 7 } & \multicolumn{3}{c}{ Baik } & \multicolumn{2}{c}{ Kurang Baik } & \multicolumn{2}{c}{ Total } & \multirow{2}{*}{ Value } \\
\cline { 2 - 8 } & $\mathrm{F}$ & $\%$ & $\mathrm{~F}$ & $\%$ & $\mathrm{~F}$ & $\%$ & \\
\hline Baik & 13 & 37 & 2 & 5.7 & 15 & 42.9 & 0.007 \\
\hline
\end{tabular}




\begin{tabular}{lllllll}
\hline Cukup & 7 & 20 & 7 & 20.0 & 13 & 37.1 \\
\hline Kurang & 6 & 17.1 & 6 & 17.1 & 7 & 20.0 \\
\hline Jumlah & 20 & 57.1 & 15 & 42.9 & 35 & 100.0 \\
\hline
\end{tabular}

Berdasarkan tabel silang diatas dapat diketahu bahwa perawat di RSUD Kota Semarang yang mempunyai pengetahuan baik tentang patient safety sebagian besar mempunyai tindakan pencegahan resiko jatuh baik sebanyak 13 responden $37.1 \%$ yang mempunyai pengetahuan cukup tentang patient safety sebagian besar 7 responden $20 \%$, dan yang mempunyai pengetahuan kurang tentang patient safety sebagian besar mempunyai tidakan kurang baik sebanyak 6 responden $(17,1 \%)$.

\section{Pembahasan}

Pengetahuan merupakan hasil dari mengingat kembali kejadian yang pernah dialami baik secara sengaja maupun tidak sengaja setelah dilakukan pengamatan pada objek yang dapat menjadi bagian penting untuk terbentuknya suatu tindakan seorang .

Berdasarkan penelitian dapat diketahui bahwa perawat di RSUD Kota Semarang yang mempunyai pengetahuan baik tentang patient safety sebagian besar mempunyai tindakan pencegahan resiko jatuh baik sebanyak 13 responden $37,1 \%$, yang mempunyai pengetahuan cukup tentang patient safety sebagian besar mempunyai tindakan kurang sebanyak 7 responden (20,0\%) dan yang mempunyai pengetahuan kurang tentang patient safety sebagian besar mempunyai tidakan kurang baik sebanyak 6 responden $(17,1 \%)$.

Hasil penelitian ini sejalan dengan teori yang dikemukakan oleh Notoatmojo (2003) yang menyatakan $b$ ahwa pengetahuan merupakan hasil dari pengindraan terhadap suatu obyek tertentu, pengetahuan atau kognitif merupakan domain yang sangat tinggi untuk terbentuknya tindakan seseorang (overbehavior). Pengetahuan merupakan pangkal darisikap, sedangkan sikap akan mengarah pada tindakan seseorang

Pengetahuan tidak selamanya didapat dari pendidikan tetapi bisa diperoleh melalui pelatihan maupun seminar (Notoatmojo, 2007). Pengetahuan dipeoeh dari pendidikan, pengajran, seminar atau pelatihan dan pengalaman itu terbukti kebenarannya. Bedasarkan wawancara yang dilakukan kepada responden, bahwa pengetahuan responden diperoleh melalui pendidikan pada waktu duduk dibangku perkuliahan dan pengalaman maupun pelatihan yang pernaj diikuti selama responden menjadi perawat.

Oleh karena itu pengetahuan seseorang akan suatu hal akan mempengaruhi perilaku perawat, hal ini sesuai dengan dikemukakan oleh Notoatmojo (2007), bahwa alas an seseorang berperilaku karena adanya beberapa faktor salah satunya pengetahuan. 
Penelitian ini didukung oleh beberapa jurnal terkait tentang hubungan pengetahuan perawat dengan penerapan identify patient correctly. Dalam penelitian sebelumnya oleh Bawelle (2013), terdapat hubungan antara pengetahuan perawat dengan pelaksanaan keselamatan pasien (patient safety) di ruang rawat inap RSUD Liun Kendage Tahuna dengan $(p=0,014)$. Pada penelitiannya yang mengemukakan bahwa pengetahuan merupakan faktor penting dalam seseorang mengambil keputusan, jurnal ilmiah Bawell (2013). Hasil penelitian lain yang juga tentang hubungan pengetahuan perawat dengan penerapan standar JCI tentang keselamatan pasien (patient safety) oleh Ginting (2014) yang menunjukkan ada hubungan yang signifikan antara variabel pengetahuan perawat dengan penerapan standar JCI tentang keselamatan pasien dengan hasil penelitian $(p=0,001)$.

Hasil penelitian ini sejalan dengan penelitian yang dilakukan oleh Bawelle (2013) Hubungan pengetahuan dan sikap perawat dengan pelaksanaan patient safety diruang rawat inap RSUD Liun Kendage Tahunan. Ada hubungan pengetahuan perawat dengan pelaksanaan keselamatan pasien (patient safety), 95\% perawat pelaksana mempunyai pengetahuan baik tentang pelaksanaan keselamatan pasien dan ada hubungan sikap perawat dengan pelaksanaan keselamatan pasien (patient safety, 95\% perawat pelaksana mempunyai sikap baik dalam melaksanakan keselamatan pasien.

\section{DAFTAR PUSTAKA}

Abdul, Majid. (2009). Perencanaan Pembelajaran. Bandung: PT.Remaja Rosda Karya. Arikunto. (2007). Prosedur Penelitian Suatu Pendekatan Praktek, Jakarta:Rhineka Cipta.

Bawelle., Sinolungan., Hamel. (2013). Hubungan Pengetahuan Dan Sikap Perawat Dengan Pelaksanaan Keselamatan Pasien (Patient Safety) Diruang Rawat Inap RSUD Liun Kendage Tahuna. Jurnal Keperawatan Ilmiah Universitas Sam Ratulangi Manado, Volume 1,1.

Darmojo. (2004). Buku Ajar Geriatri. Jakarta: Balai Penerbitan FKUI

Departemen Kesehatan R.I. (2008). Panduan Nasional Kesehatan Pasien Ruma Sakit (Patient Safety). Jakarta. Bhakti Husada.
Departemen
Kesehatan
R.I. (2012). Panduan
Pasien Rumah SakitUtamakan Keselamatan Pasien. Bakit Husada.

Nasional Keselamatan

Ginting. (2008). Filsafat Ilmu Dan Metode Riset. Medan: USU Press

Herlina., Setyarini. (2013). Kepatuhan Perawat Melaksanakan Standar Prosedur Operasional Pencegahan Pasien Resiko Jatuh Di Gedung Yosef 3 Dago Dan Surya Kencana Rumah Sakit Borromeus. Jurnal Keperawatan Ilmiah Stikes Santo Borromeus.

Hughes., Richard. (2006). Leadearship Enhacing The Lesson Of Experience. New York: Mc Graw-Hill.

Joint Commision Acriditation Of Health Organization. (2002). "Hospital Patient Safety Standards". USA: Illinois.

Lumbantobing. (2006). Neurogeriatri. Jakarta: FKUI. Mar'at. (2005). Sikap Manusia, Perubahan Serta Pengukurannya. Bandung: Ghalyn. Notoaatmodjo. (2007). Promosi Kesehatan Ilmu Dan Seni. Jakarta: Rineka Cipta. 
Nugroho. (2008). Keperwatan Gerontik. Edisi 2. Jakarta: EGC.

Nursalam. (2008). Konsep \& Penerapan Metodologi Penelitian Ilmu Keperawatan. Jakarta: Salemba Medika.

Peraturan Menteri Kesehatan Republik Indonesia Nomor 1691/MENKES/PER/VII/2011 Tentang Keselamatan Pasien.

Riyanto. (2011). Teknik Sampling Analisa. Yogyakarta Pelangi: Aksara.

Sastroasmoro. (2011). Dasar-dasar Metodologi Penelitian Klinis. Jakarta: Sagung Seto. Sjamsuhidajat., Jong. (2005). Buku Ajar Ilmu Bedah. Jakarta: EGC.

Stanley., Bare. (2006). Buku Ajar Keperawatan Gerontik (Edis2). Jakarta: EGC.

Sugiono. (2007). Statistik Untuk Penelitian. Bandung: CV.Alfabeta.

Sunaryo. (2004). Psikologi Untuk Perawatan. Jakarta: EGC.

Supari. (2008). Pencanangan Gerakan Keselamatan pasien Rumah Sakit. Jakarta: ECG.

World Health Organization. (2012). Safety Is Fudamental Principle Of Patient Care And Critical Component Of Quality Management. http://www.who.int/en.

Yahya., Adib. (2009). Buku Konsep dan program "Patient Safety”. Bandung: Angkasa Bandung. 